\title{
THE STRANGE FATE OF WHITMAN'S BRAIN
}

\author{
BRIAN BURRELL
}

On December 5, 1907, the Philadelphia North American hedged its bets when it ran the day's top story, somewhat ambiguously, under the banner: "Brain Research by Phila. Anatomist Startles Science." It was either the scientific breakthrough of the year, or simply a very loud false alarm. As it turned out, the alarm was a false one, and science resumed its former course. Yet something buried deep in the article caused an uproar that has yet to die down. It was not exactly what the anatomist had in mind.

His name was Edward Anthony Spitzka, and the occasion was the release of his landmark study on the long-sought-after link between brain anatomy and intelligence. Spitzka thought he had mastered the phrenological trick of divining the quality of the mind through the shape of the brain, which would have been startling indeed.

He certainly had the right credentials for the job. The son of the renowned alienist Edward Charles Spitzka, he first gained national attention in 1901 for a feat that would be unthinkable today. While still only a medical student, Spitzka was chosen to perform the autopsy on the presidential assassin Leon Czolgosz and to inspect the murderer's brain for signs of degeneracy. He found none, but his published report was widely praised, and the young anatomist soon found a callingexamining the brains of criminals in search of structural clues to their behavior. After getting his medical degree, Spitzka signed on at Columbia as a demonstrator of anatomy, and began to attend executions at local prisons. In a ritual repeated dozens of times, he would arrive at Sing-Sing, Auburn, or Dannemora with a small satchel of tools, and depart with a fresh brain. In 1903, drawing upon a sizable collection of these specimens, he wrote a monograph on the effects of electrocution on brain tissue.

At the same time, Spitzka began to collect and examine brains of an altogether different type-those of accomplished men such as the explorer John Wesley Powell and the merchant George Francis Train. As his reputation grew, it became easier for Spitzka to acquire such brains. In some circles, leaving one's brain to science had become down- 
right fashionable, to the extent that brain collection societies started popping up in research communities around the world. By gaining access to the most prestigious of these societies, Spitzka was able to embark on his massive project, and his career blossomed. In 1904 he accepted a chair in anatomy at Jefferson Medical College. As one of the few medical professors in the country whose salary did not force him to maintain a private medical practice, he had the luxury of pursuing a research program of his own choosing. Spitzka chose to gamble everything on the study of these brains of eminent men, which he believed to be in a class by themselves.

Had Spitzka been right, it would not be necessary to explain who he was. His name would be engraved on the facades of science classrooms across the country. Of course he was not right, and his discovery sank like a stone, although the North American had one thing right: Spitzka did indeed startle many scientists, if not poetry lovers. For it was in his 1907 magnum opus - "A Study of the Brains of Six Scientists and Scholars belonging to the American Anthropometric Society" - that Spitzka, in what was little more than a throwaway comment, revealed the sad fate of the brain of Walt Whitman, how it slipped out of the hands of a laboratory assistant, broke into pieces, and was discarded. Had Spitzka any idea what would come of that comment, he would probably have kept his mouth shut.

The loss of Walt Whitman's brain has thus far defied all attempts at simple explanation. It didn't make sense. Spitzka, of all people, would have known that a hardened brain would not easily break into pieces, that even if damaged, it would still be of scientific use. His choice of words didn't help. The brain "was said to have been dropped." By whom? And where? Spitzka placed the blame on a "careless attendant in the laboratory," conjuring up images of Fritz on a midnight mission for Dr. Frankenstein. The story satisfied no one.

A few years later, Whitman's friend William Sloane Kennedy contacted Professor Herbert T. Harned, the son of Thomas Harned, to see if he could learn anything new. After making some inquiries, Harned informed Kennedy that the brain "was destroyed either during the autopsy or while being conveyed to the jar, or in the jar before the hardening process by formaldehyde had been completed." He cited an unimpeachable source, Henry Donaldson, a highly respected physiologist and the research director of Philadelphia's Wistar Institute of Anatomy and Biology, where the brain would have come to reside had it survived. According to Harned, "Dr. Donaldson looked the matter up in the files of the Wister [sic] Institute, and told me that the records state quite definitely that the brain was accidentally broken to bits during the pickling process." Kennedy filed the letter with his other Whitman memorabilia in his Big Canvas-Covered Scrap-Book, as he called it, adding the comment, "This is a grewsome story!" 
"Grewsome" it is, and maddeningly unsatisfying. Harned suggests not one, but three possible scenarios: the brain was destroyed at Whitman's Mickle Street house, en route to the lab, or at the lab. There is something odd about proposing three theories, only to have Donaldson state "quite definitely" that the accident occurred during the preservation process - in other words, in the lab. Why bother mentioning the other scenarios? It could be to draw attention away from a problem. If, as Donaldson says, the brain was dropped before the hardening process was complete, the Wistar Institute has to be ruled out. The building first opened its doors in the fall of 1894, two-and-a-half years after Whitman's death. Jefferson Medical College has also been proposed as the scene of the crime. The day after Spitzka's announcement, the Camden Daily Courier reported that the brain was lost "through the careless handling by a minor employe in the Jefferson College." 2 But as will become clear, there are good reasons to exonerate Jefferson as well. All of which seems to lead ... nowhere. Or, more accurately, to the trash-heap of urban folklore.

And yet, even though the mystery of Whitman's brain seems to defy explanation, there is one. Buried deep in Spitzka's carefully chosen words, or more specifically in what he was careful not to say, there lies a plausible scenario, one that can explain away all of the seemingly contradictory evidence. Spitzka knew more than he was letting on, but he had a good reason to remain silent. To place the blame where it belonged, he risked antagonizing the very organization for which he had just become a spokesman. He also risked losing access to an unending supply of elite brains.

Edward Spitzka's "A Study of the Brains of Six Eminent Scientists and Scholars" is a long and fascinating document that begins with the event that sealed the fate of Whitman's brain. Sometime in the fall of 1889 (Spitzka mistakenly places the event two years later), five distinguished gentlemen gathered at the Spruce Street home of William Pepper, the provost of the University of Pennsylvania, to share some food and drink, and to launch an unusual venture. Inspired by a relatively new field of study called physical anthropology-the study of man as a physical entity - they decided to form a society devoted to collecting and measuring the brains of eminent men, starting with their own. To emphasize the broad scope of their plan, they called it the American Anthropometric Society.

The other founders included Spitzka's father, Edward Charles Spitzka, an expert on insanity from New York, and three Penn professors: Harrison Allen, a comparative biologist, Francis X. Dercum, a specialist in nervous diseases, and Joseph Leidy, whose scientific cre- 
dentials defy a brief summary. As his biographer put it, Leidy was, quite simply, "the last man who knew everything." 3 Each of these men nursed a fascination with the human brain (among many other things) and pursued its study to the degree that their busy schedules would allow, which was not very much. They were gentleman scientists of the Victorian era, in an age before specialization edged out the kitchen table researcher. Frustrated by the state of elite brain research on both sides of Atlantic, a hodge-podge of post-mortem studies of great men, the Philadelphia scientists decided to take matters into their own hands. They would volunteer their own brains and encourage their peers to do the same. In time, they hoped, the brains would accumulate, plaster casts would be made and distributed to surviving members, and in this way an archive of exemplary brains would become available to future researchers. If a link between cortical structure and personality existed, they would surely find it, or their successors would.

The Brain Society, as it was sometimes called, was an instant success. In less than a year dozens of their esteemed peers had enthusiastically signed on. But like many of the fraternal societies that were springing up at the time, the A.A.S. emphasized initiation at the expense of results. Silas Weir Mitchell, an early joiner and Whitman's physician in the 1880 s, once said of such clubs that they were little more than pretexts for the consumption of terrapin and Madeira. The fate of the brains seems to confirm it. When the younger Spitzka stepped in to take over the project in 1902, a decade into the collection phase, he could locate only seven of the ten catalogued brains, and of these, four had been damaged through neglect or mishandling, while two others had been improperly weighed. It was a pretty sorry record.

In a preliminary report to the membership in 1906, Spitzka felt obliged to enumerate these set-backs. ${ }^{4}$ The brain of Dr. Andrew J. Parker, he wrote, had been left in Müller's fluid, a hardening agent, and had crumbled to pieces. Fortunately a plaster cast had been made, allowing it to be included in the study. The brain of Professor J. William White had suffered irreparable damage, and no cast existed. A total loss. The brains of Harrison Allen and William Pepper had become flattened in their jars, yet retained enough of their shape to be of use. The weighing of Joseph Leidy's brain had been botched, and the fresh brain weight could only be estimated. Three of the brains were missing. Those of the pioneering psychiatrist Isaac Newton Kerlin and his wife Harriet, said to be in the possession of the society's first prosector, Dr. Henry Cattell, were not made available. Spitzka declined to say why. The other brain that should have been in Cattell's care inspired Spitzka's shocking and now familiar revelation: "The brain of Walt Whitman, together with the jar in which it had been placed, was said to have been dropped upon the floor through carelessness in handling. Unfortunately, not even the pieces were saved." 5 
Spitzka seems to have viewed the loss of these brains as unfortunate, but hardly catastrophic. He had been working with elite brains since 1899, and had enough data to fill 133 folio sheets in his 1907 study. The first section of the paper is a tour de force. In it, he catalogues 137 case studies of brains of accomplished men and women, followed by eight "doubtful reports" (including Oliver Cromwell, Lord Byron, Franz Schubert, and Blaise Pascal), in many instances giving detailed accounts of how the brain was acquired, what it looked like, who removed it, and what became of it. In the era that gave rise to the notion of history as the biographies of great men, Spitzka presents the history of neuroscience through the postmortem reports on great brains, including those of Daniel Webster, Napoleon III, and Hermann Helmholtz. In the last five pages, Spitzka makes the case for a number of claims: that brain weight does matter, that convolutional development and fissural patterns do reflect, in a general way, certain talents and skills, that eminent men possess a greater development in the frontal lobes than do ordinary men. None of this was new, but he had withheld his trump card. By measuring the cross-sectional area of the fiber bundle that connects the left and right hemispheres (the corpus callosum), he found, with only one exception, that the callosa of eminent men are larger than those of average men. With that, Spitzka thought, he had redeemed the sacrifice of the founders of the Brain Society. He had discovered "an index in somatic terms of the distinction between brains of geniuses or of talented men and of persons of only ordinary abilities." Or had he?

Two days later, bad news greeted Spitzka at the breakfast table on the front page of the North American: "Scientists Attack Dr. Spitzka's Brain Structure Theory."7 It turned out to be worse than that. His colleagues had damned him with faint praise. Politely and respectfully, and with full appreciation of his laudable efforts, they refused to endorse his conclusions. He had failed to take into account the varying degrees of shrinkage in the specimens, they said. To make matters worse, the Whitman story garnered an equal share of newsprint. According to the Camden Daily Courier, it caused a "profound sensation":

When the executors of the late Walt Whitman in Philadelphia were informed of the loss of the brain of a philosopher they declared it was a breach of implied trust. Horace L. Traubel, literary executor of the will, declared that none of the executors of the will had ever been informed that the brain had been lost to science. . . . [He] said: "I cannot understand it. The fact that such an institution should permit the care of such a precious property to an attendant who probably had no idea of the value of what he was handling is bad enough. But that they should permit the brain to be lost and then fail to notify the executors of Walt Whitman's estate, I consider worse. I cannot say just what action will be taken in the matter, but it will be taken up immediately and rigid inquiry made to place the responsibility for what seems to be gross carelessness. The executors will meet tomorrow to decide just what shall be done . . . I I hardly think we have been treated fairly, and decidedly some action will be taken." ${ }^{8}$ 
It was not. Most likely, Traubel was quietly informed that Jefferson College was not to blame, that the brain had never been there. According to George C. Vail, former director of the Camden Historical Society, "neither the college nor the executors made public comment afterward." The newspapers also declined to pursue the story beyond a few questions lobbed at Spitzka. Who was responsible? Had anyone actually studied the brain? A plaster cast was supposed to have been made. Where was it? In a huff, Spitzka brushed off all such inquiries, saying that he had nothing to do with it. ${ }^{10} \mathrm{He}$ was just the messenger. But he must have experienced a sinking feeling that his magnum opus was dead on arrival, while the story of the brain of the poet had taken on a life of its own.

The story was in fact bigger than Spitzka could have imagined, and it began long before his father sat down to dinner with his four distinguished colleagues.

When Mary Shelley wrote Frankenstein she made no mention of brains. To anyone who comes to the legend via the 1931 film instead of the 1818 novel, this might seem odd. But then the legend of Frankenstein has changed considerably since Shelley's time in order to keep in step with the science that inspired it. If there are no brains in jars in Frankenstein the novel, it is because at the time she conceived the book, there were no brains in jars at all, and there would not be any for some time to come. The modern preoccupation with the human brain, it turns out, is a relatively recent phenomenon. Before Shelley's time, very few people gave it much thought.

The most important exception was a diminutive Viennese physician named Franz Josef Gall, the man who laid out the basic tenets of what would come to be called phrenology at the dawn of the nineteenth century. For the record, Gall did not practice phrenology. Instead he practiced something he called organology, according to which:

i. The moral and intellectual dispositions are innate.

ii. Their manifestation depends on organization.

iii. The brain is the exclusive organ of the mind.

iv. The brain is composed of as many particular and independent organs as there are fundamental powers of mind. ${ }^{11}$

Regrettably, the failure of phrenology has obscured Gall's greatest contribution to science, for it was Gall who focused the world's attention on the human brain by insisting that everything related to the mind sprang not from the liver, the heart, or the spleen, but from the head. He went further by suggesting that the brain is not a unified entity that 
produces thoughts, but a multi-tasking device made up of regions of specialized function. He had invented none of this. Individually, each of these ideas had been afloat for some time. Gall's innovation was to combine them into what is still the modern paradigm of brain and mind.

Resistance to Gall's theory was instant and fierce. To suggest that the mind results from physical processes called into question the very existence of an immortal soul. Gall protested that he intended no such thing, but to no avail. He was run out of Vienna as a godless materialist. This might have been seen in hindsight as heroic, had not Gall augmented his organology with something else he called cranioscopy, his "doctrine of the skull," by which he proposed to gauge a man's character by examining the bumps on his head. By the time he arrived in Paris, in 1802, Gall was already the object of ridicule. Like Darwin, he was right about one big thing and wrong about many lesser things. But unlike Darwin, his followers chose to promote his mistakes over his core argument. ${ }^{12}$ Gall had invented a faculty psychology which he augmented with a parlor trick. To his ultimate chagrin, the parlor trick would end up stealing the show.

Given that the brain was the focus of Gall's theory, it may seem odd that instead of collecting brains, he collected skulls. There is a simple explanation. Brains are exceedingly difficult to remove and preserve. So delicate is the human brain that it is the first part of the body to start to decompose after death. (A Soviet neuroanatomist once likened it to the insides of a watermelon.) Once removed, it does not hold its shape very well, even in a jar of preservative. Moreover, preserving a brain is not simply a matter of plopping it into a jar. The process involves a sequence of injections and baths that require several weeks' worth of daily attention, after which the specimen can be easily handled, although the pickling can reduce its mass by as much as thirty percent. The French anatomist Felix Vicq d'Azur devised the first method for preserving a brain specimen in 1789 , but it was far from perfect. No one consistently got it right until the mid-1800s, which partly explains why Mary Shelley did not send Victor Frankenstein out into the night to acquire a brain in a jar.

Another notion central to the Frankenstein legend, the idea that drives the plot of the film, was similarly unavailable to Mary Shelley. In one of the film's famous set pieces, Dr. Waldman ends an anatomy lecture by comparing a healthy, normal brain to the brain of a demented murderer. The dialogue comes straight from Cesare Lombroso's theory of criminal anthropology, and from the Viennese psychiatrist Moritz Benedikt's 1878 Anatomical Studies on the Brains of Criminals. It was Benedikt who first proposed that criminals are of a distinct anthropological type, that their brains are easily distinguished from those of lawabiding citizens. ${ }^{13}$ Yet Shelley had set out to make the opposite point, that environment shapes personality. She dismissed the materialist no- 
tion that the choice of a brain would determine the fate of her creature. But her thesis would be subverted when Robert Florey, the director originally assigned to the $1931 \mathrm{film}$, wrote the scene in which Fritz breaks into the lecture hall following Dr. Waldman's presentation, drops the healthy brain, and takes the defective brain in its place. ${ }^{14}$ (Although impossible to prove, it seems likely that the fate of Whitman's brain served as the model for this inspired bit of screenwriting.)

In 1824, eight years after suggesting to Mary Shelley (then Godwin) that she write a ghost story, Lord Byron died in Missolonghi, and his brain was removed at autopsy and weighed. This was not a standard practice, but the efforts of German physicians at the dawn of the nineteenth century had made post-mortem examinations acceptable, and besides, Byron was a special case. He was one of the first, and perhaps the most prominent exemplar of Romantic genius. What is more, he had a very large head. Just how large is uncertain. The recorded brain weight of "six medicinal pounds" failed to specify whether Neapolitan, Venetian, or English units of measure were used. ${ }^{15}$ Spitzka concluded that the figure was unreliable, and so he did not include the brain in his statistical analysis. Even so, Byron would become exhibit A for the phrenological contention that great intellects are housed in large brains. Materialism was now gaining momentum. Other compelling exhibits soon followed.

Three years later, when Beethoven died in Vienna, the physicians who performed the autopsy decided to remove and set aside the temporal bones of his skull in the hope of determining the cause of his deafness. They were not looking for the source of his musical genius. They did not remove the brain. But they did look at it closely enough to note that the convolutions "appeared twice as numerous and the fissures twice as deep as in ordinary brains." 16 The implication was obvious: Beethoven was twice the musician anyone else was. Here, possibly, was the reason why.

A year later, in 1828, Gall himself died, and his brain was removed, weighed, and examined, but also not preserved. ${ }^{17} \mathrm{He}$ would have known this was coming. He had inspired anatomists to look at the brain in a new way. He just hadn't told them precisely what to look for. The brains of Byron and Beethoven, even his own, seemed to confirm that the brains of eminent men are larger than those of ordinary men, that their complex surface patterns in some way correlate with intellectual prowess. But learning how this correlation played out would require a systematic comparison of brains, all of them removed and preserved in the same way. Like Gall's collection of skulls and plaster busts, these brains would have to come from all walks of life, with special emphasis on men of 
distinction. And they would have to be studied by someone with the right credentials. It would not be easy. An opportunity to conduct a study of this sort does not come along very often, and has everything to do with luck.

In 1855, the year Leaves of Grass was first published, a physiologist at the University of Göttingen got lucky. Rudolph Wagner, a wellrespected professor of anatomy and physiology, attended the autopsy of the great mathematician Carl Friedrich Gauss and came away with Gauss's brain, which he carefully preserved for future study. It is not clear how Wagner got the blessing of Gauss's son, but in doing so he set an important precedent in the study of famous brains: possession would thenceforth become nine-tenths of the battle. A retroactive permission, it was discovered, could usually be obtained by invoking "the interests of science." (Whitman would prove to be another case in point.) Although some important brains had been preserved before this, none could compare to Gauss's. He was an undisputed scientific genius, still considered, along with Archimedes and Newton, as one of the three greatest mathematicians ever to have lived. And thanks to Gall, it was possible to imagine that it had everything to do with the structure of his brain. Whether this was true or not, in one stroke Gauss's brain inspired and legitimized Wagner's new research program. Over the next five years, this celebrated specimen made it possible for him to acquire the brains of four other Göttingen professors, as well as the brains of several townsfolk. He now had his sample. Wagner then immersed himself in the study of brain anatomy, and in 1860 published his initial results. ${ }^{18}$

Wagner was an impeccable technician, and the brains he preserved are still remarkably intact to this day. (Four of them, including Gauss's, are on display in Göttingen.) He was also a talented and accomplished research physiologist, and his study still reads like a model of scientific reasoning. He had done his homework by poring through autopsy records of over 950 individuals, ranging from the educated to criminals to the insane. He catalogued all of them, including pathological cases, listing them in descending order of brain weight. Setting aside two macrocephalic cases, the brains of Byron and the French naturalist George Cuvier stood alone atop the list. Surprisingly, Gauss failed to crack the top hundred.

As much as Wagner would have liked to have found something special in Gauss's brain, he did not. At least nothing that would explain the man's unquestionable genius. The brain was above average in size, but just barely. A local laborer had an even bigger brain. Gauss's hemispheres possessed a remarkable complexity of surface fissures, inspiring Spitzka a half-century later to refer to similarly tortuous brains as being "of the Gauss-type." Yet Wagner found many brains of ordinary men 
and women that fit the same description. Seeing no direct correlation between structure and achievement, between the size of the brain and the thoughts it produced, he was forced to conclude that brain weight and fissural complexity did not always signify a superior mind. There were too many exceptions to the rule.

Wagner's Vorstudien was widely read among scientific materialists, who disliked both the message and the messenger. Wagner, a conservative, had spoken out against materialism and in defense of the immortal soul in a series of heated debates that had gained him a reputation in scientific circles as a hopeless reactionary. Critics were only too happy to criticize his results, or lack of them. In Paris, where the surgeon Paul Broca had helped to found an anthropological society, Wagner's research set off a year-long debate pitting the materialists (mostly Protestant) against the anti-materialists (who tended to be Catholic and Royalist).${ }^{19}$ Broca hoped to revive the phrenological theory of cerebral localization, and in 1860 he found evidence of a speech area (now known as Broca's area) in the left frontal lobe. Although the debates he moderated at the Société d'Anthropologie were otherwise short on scientific evidence and very long on rhetoric and metaphysics, they did succeed in placing the study of man on a scientific basis. More and more, this study began to focus on the human brain.

In the wake of Wagner's Vorstudien, elite brain studies became increasingly popular. Autopsy reports accumulated, and with them lists of brain weights of famous men, including such luminaries as Daniel Webster, Gaetano Donizetti, William Whewell, George Grote, Robert Schumann, Louis Agassiz, and Ivan Turgenev, whose brain would top all lists at 2012 grams (compare this with Whitman's 1282 grams). ${ }^{20}$ Unfortunately, such reports failed to meet the minimum standards of uniformity for large studies. Each brain was removed, weighed, and preserved according to the whim of the pathologist. Age at death, method of removal, and the physical condition of the deceased were hardly taken into account. And because no standardized method of measuring and describing the parts of the brain yet existed, brains continued to be compared solely on the basis of weight. Wagner alone had managed to collect, examine, and document a series of brains under adequate controls. Despite its author's unpopularity, his study remained unsurpassed.

In 1876, a faction of radical materialists within Broca's Société d'Anthropologie decided to do something about this. With a flair for the bizarre, they formed the first brain donation society. They named it, rather eerily, the Société Mutuelle d'Autopsie (the Society of Mutual Autopsy). ${ }^{21}$ In their revolutionary fervor, they sealed their compact with a pledge that had the portentous ring of a fraternal oath: "Free thinker, loyal to scientific materialism and the radical Republic, I intend to die without the interference of any priest or church. I bequeath to the School of Anthropology my head, face, skull, and brain, and more if it is neces- 
sary. What remains of me will be incinerated." 22 The gesture seemed selfless, the aim laudable, and the ultimate payoff discouragingly distant. Few early joiners could hope to be in on it. It would take time for the brains to accumulate.

Other brain societies soon appeared, most notably in Stockholm and Ithaca, New York. ${ }^{23}$ But the most promising spin-off of the Mutual Autopsy Society was the Anthropometric Society of Philadelphia, whose members were not hampered by any political agenda. Which is not to say that they had no agenda at all. If all went well, they hoped to confirm the anatomical superiority of eminent men like themselves.

Walt Whitman's interest in brains in general, and in his own brain in particular, could hardly have come about any sooner than it did. In a way, he got in on the ground floor of a growth industry when he strolled into the Phrenological Museum of Orson Fowler and Horatio Welles in 1849 to have his chart of bumps read. His reasons for going have been examined in detail by several writers, notably Edward Hungerford, who also explored the phrenological influence on the poems, how the language of phrenology seeped into his writing. ${ }^{24}$ What he failed to explain is why Whitman later soured on the subject, why he decided to delete or replace some of the phrenological references in later editions of his work. It is easy to blame the crippling strokes, the betrayal of his perfect body by his perfect brain. But Whitman's pre-stroke belief in his physical perfection has been revealed to be something of a myth by Harold Aspiz, who points out what Whitman knew long before 1873: that poor health, neurological disorders, and even mental illness ran in the Whitman family, that his chronic headaches might be a portent of dire things to come. ${ }^{25}$ Initially, phrenology provided Whitman with one more way to celebrate not only his own physicality, but the physicality of America itself. After the Civil War it left him struggling to explain his own physical decline.

Some of his disillusionment can be explained by the company he kept. Whitman's discovery of phrenology coincided with that of many American physicians, who at first saw its potential for freeing medicine from superstition and religion, but then abandoned it when its scientific underpinnings proved faulty. Silas Weir Mitchell and William Osler, Whitman's physicians during the Mickle Street years, had little patience with the phrenological Fowlers. Mitchell's own father, the renowned physician John Kearsley Mitchell, had practiced phrenomagnetism in the 1830s. But Weir Mitchell and Osler were a new breed: experimental researchers. After their own brief flirtations with phrenology, they too rejected its pretensions to science. Instead they pinned their hopes on cerebral localization, on the identification of regions of special function in the human cortex by experimental methods including vivisection, 
electrical stimulation of the cortex of animals, and observations of victims of strokes with post-mortem examination of brain lesions. After Broca's discovery of the speech center by just such a procedure, morbid anatomy had become the cutting edge of neurophysiological research.

For Whitman, it was all too technical. In his early poems he latched onto materialist science, appropriated terms from electricity and animal magnetism to produce metaphors that sometimes betrayed an ignorance of scientific principles. As early as 1860 , he began deleting some of the more offending passages. ${ }^{26}$ The more he read and the more he learned first-hand of medical practice, the more his enthusiasm for some of these ideas cooled. The limits of that enthusiasm were tested by the failure of his own "beautiful brain," a problem whose organic nature he admitted in his daybooks when he referred, as he often did, to "brain trouble." 27 Still, he never quite relinquished his wonder at "the fathomless human brain," as he wrote in "Song of Myself," or came to terms with its "occult convolutions." 28 It seems likely that even in the last year of his life he would have been eager to contribute to unlocking its secrets. But he no longer trusted phrenology with the job.

Sometime in 1888 he said to Horace Traubel, "I know what [Oliver Wendell] Holmes said about phrenology — that you might as easily tell how much money is in a safe feeling the knob on the door as tell how much brain a man has by feeling bumps on his head: and I guess most of my friends distrust it - but then you see I am very old fashioned-I probably have not got by the phrenology stage yet." ${ }^{29}$ But he in fact had "got by" the phrenologists and had cast his lot with the new generation of professionals. Of Mitchell, he would say, "he's a world doctor for sure-leastwise everybody says so and I join in." ${ }^{30}$ His opinion of Osler was similarly rooted in the opinions of others. He had no idea that Mitchell would be hailed as the father of American neurology or that Osler would become the patron saint of modern clinical medicine. But he liked both men, believed in them, and predicted great things for them. If they or their colleagues had told him that his brain would be of value to science, he would not have doubted it. The question is: did they ever ask for his permission to study it?

A week before he died, as he scanned the death notices, Whitman came upon a familiar name. "Dr. Parker's dead," he remarked to his friend and physician, Daniel Longaker. ${ }^{31}$ Astounded that Whitman's obsession with the dailies still thrived despite his almost complete physical collapse, Longaker at first did not realize whom he was talking about. "To which Parker do you refer?" he asked. "Dr. Parker of Philadelphia," said Whitman, "you must know him-Dr. Andrew J. Parker." Longaker was quick to reply that he did indeed know Parker as "the pupil, disciple, and friend of Leidy and a quizmaster in the University when I was a student there seventeen years ago." 
Why did Whitman single out this obituary? Could it have been that all three men-Whitman, Parker, and Longaker - were members of the same secretive brain society? There is good reason to believe that Longaker was. His predecessors as Whitman's physician-Silas Weir Mitchell and William Osler-made no secret of their affiliation. Nor did Mitchell's son, J. K. Mitchell, who also became part of the Whitman circle in the late-1880s. As an 1881 graduate of Penn Medical School, Longaker had studied under the society's founders, and he remained in close contact with them during the year in which he treated Whitman. Parker, in particular, would have been well known to him, to the extent that he had probably heard the rumors about Parker's death before Whitman read about them. When a full account of the incident appeared in the papers, Whitman was moved by it. "It is tragic," he remarked to Horace Traubel, "an early fall-inexplicable. But why do I say that: what is not?"32

Andrew Parker's death was not a complete mystery. What makes it interesting is that it marks the only reference to the Anthropometric Society (albeit an indirect one) that Whitman ever made in Horace Traubel's presence. The article that probably caught his eye ran in the March 22 edition of the Philadelphia Press under the nested headlines "Willed His Brain To His Colleagues," and "A Brilliant Life Ended by an Illness Peculiar and Pathetic." If Whitman did not already know that Parker belonged to the Brain Society, the article would have confirmed it.

The events leading up to Andrew Parker's death were unusual enough, even scandalous enough, to have been suppressed for several days. He died on Friday, March 18, and the circumstances slowly leaked out. By the time it made the headlines four days later, it had become the talk of the town.

Parker, a former professor of biology at the University of Pennsylvania, had recently returned to the city to conduct some brain research in his old lab. (This research would be published posthumously by Francis Dercum in the fournal of the Academy of Natural Sciences. $)^{33}$ By all accounts, Parker was a brilliant, if somewhat odd, fellow who showed great promise but little perseverance. He couldn't seem to settle down. ("His tastes were rather Bohemian and unconventional," wrote Spitzka. "His dilatory habits interfered with the publication of his experiments, and to this his steadily increasing ill health also contributed.") $)^{34}$

On Monday, March 10, Parker was so ill that his friends became alarmed. They instantly arranged for a room and a nurse, which suggests that Parker had been living in a hotel. Despite round-the-clock care, Parker's condition worsened. He became delirious. On 'Thursday, while unattended, he stole from his room, entered a nearby house, went upstairs, undressed, curled up over a heat register and went to sleep. When discovered by a lady of the house, there was a scene (as the man 
from the Press put it), and the police carted Parker off to the hospital. When he learned that he had been taken to German Hospital and not University Hospital, as he had requested, Parker threw a fit and insisted on being moved. The attending physician told him he was in no condition to leave, but Parker became so agitated that the doctor relented and called an ambulance. Before it could arrive, Parker escaped (after two tries) and was picked up a block away. He was then taken to University Hospital. He never recovered. "Before his death he gasped that he never felt better in his life," according to the Press. Francis Dercum performed the autopsy. The cause of death was a blood clot due to pneumonia.

Had Whitman scanned the last paragraph, he would have seen this:

He was a prominent member of the American Anthropometric Society, to which in accordance with the custom of the members he years ago willed his brain. This has been turned over to the society and an examination shows that it weighs ... above the average weight and one ounce heavier than the brain of the late Professor Leidy. ${ }^{35}$

Whitman mentioned the death to both Longaker and Traubel without mentioning his own involvement with the society. If he was indeed a member, he failed to put it in writing, and his failure to divulge this to anyone close to him would create a commotion a week later, when he lay dead in his own bed, and Professor Dercum was called out once again.

When Joseph Leidy died unexpectedly in 1891, Harrison Allen performed the autopsy and removed the brain, with Francis Dercum assisting. Just twenty-three hours earlier, Leidy's brother Philip, a physician, had died, and Dercum had removed the brain, with Allen assisting. No one had expected two prominent members of the fledgling brain society to die so soon, and their sudden deaths highlighted a thorny problem. Dercum and Allen had to be ready to go out at any time of day, in any conditions, to acquire the brain of a deceased society member. The task did not end there. Someone would have to preserve the brains as they accumulated, store them, study them, make casts, distribute them, and so on. The two professors were not up to it.

Like most of their peers, Allen and Dercum divided their time between teaching, consulting, maintaining a private medical practice, conducting research, writing books and monographs, and attending meetings of scientific societies. Dercum is an interesting case in point. His entry in the National Cyclopaedia of American Biography lists memberships in twenty-four societies (without mentioning the Brain Society) and five clubs. He consulted at eight hospitals. He was also actively 
involved in research. Four years earlier, he and Allen had collaborated with Eadweard Muybridge on his photographic studies of animal locomotion. ${ }^{36}$ (Pepper had funded the project, Leidy and Thomas Eakins had helped oversee it, and Dercum and Allen provided subjects and wrote monographs to accompany the images.) Since then the demands on their time had increased. If the task of collecting and caring for the brains was going to be done right, they would have to hire someone for the job.

Fortunately, a qualified candidate was already on hand. Henry Ware Cattell, an 1887 graduate of the University of Pennsylvania medical school, had returned to Penn in 1892 as a demonstrator of morbid anatomy under Francis Dercum. Unlike many of his peers, he had not established a private medical practice. Instead, he divided his time between teaching, consulting, and medical editorial work. Cattell accepted the position of prosector for the society in 1892, and was initiated into the role by assisting Dercum at Andrew Parker's autopsy. Within a week, he would set off with Dercum again, this time in the direction of Camden.

A prosector is the person who wields the knife at an autopsy or a classroom dissection under the watchful eye of the supervising physician. When Spitzka performed the autopsy on the presidential assassin Leon Csolgosz, he did the cutting for Carlos MacDonald, the anatomist of record. At Whitman's autopsy, Dercum is said to have removed the brain, but most of the routine work would have been performed by Cattell, who was an accomplished pathologist in his own right.

In 1894 Cattell put together a book from his lectures entitled Notes on the Demonstrations in Morbid.Anatomy (Including Autopsies) Delivered in the Medical Department of the University of Pennsylvania Before the ThirdYear Class. ${ }^{37}$ Whitman's autopsy would have been fresh in his mind when he wrote, in great detail, about the process of removing a brain. Anyone interested in what went on in the parlor at Mickle Street, in what Traubel meant by the "claw and dip of the instruments," can consult Cattell's Notes or his follow-up volume, Postmortem Pathology (1903), ${ }^{38}$ both of which leave little to the imagination (see Figures 1 and 2).

Equally instructive, if not just as "grewsome," is Cattell's description of the tools, especially the portable autopsy kit. The essential tools are few, and among them should be "a piece of oil-silk or a special bag so prepared that fluid will not escape from it." ${ }^{39}$ In his pathology text, he refers to it as "a rubber bag (sixteen by ten by four inches) from which fluid will not escape." 40 Horace Traubel gave it another name. "When the brain was extracted," he wrote, "Cattell put it into his gupsack." (Although not found in dictionaries of the era, the word evidently means a gutta-percha sack.) The ideal vessel, of course, would have been a museum jar. 


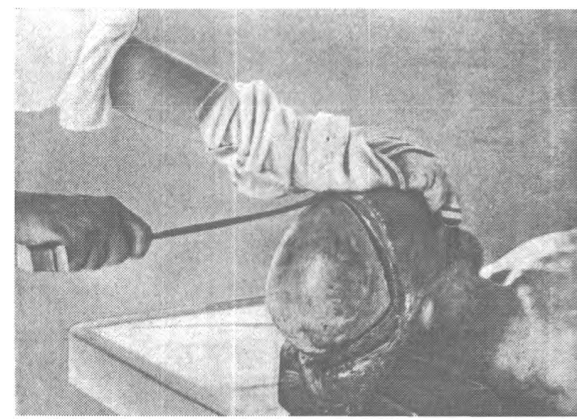

Figure 1. Illustration from Henry W. Cattell's Postmortem Pathology (J. B. Lippincott, 1906), 236.

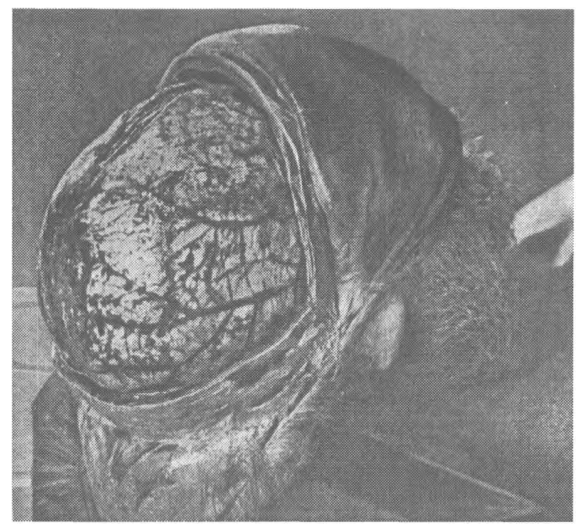

Figure 2. Illustration from Henry W. Cattell's Postmortem Pathology (J. B. Lippincott, 1906), 239.
Cattell also devotes a paragraph or two in each of his books to the delicate issue of permission, not just permission to perform the post mortem, but permission to take away the organs. "You should be sure you have the right to make the post-mortem before you begin," he writes. "The nearest relative, or the one who is going to pay the expenses of the funeral, should give consent in writing." 42 In Whitman's case, Cattell heeded none of these warnings. According to the Press: ${ }^{43}$

The question of an autopsy ... was broached to the brother [George Whitman]. He expressed the strongest objection to it. If he were satisfied that any scientific end was to be attained by a postmortem examination he would agree to it, but he felt that the only purpose of such a course of action on the part of the doctors was the satisfaction of professional curiosity.

George Whitman's wife Louisa was more sympathetic to the idea, but stuck by her husband. After repeating their objections, they left Walt's house at noon and returned home. At 5:30, Dercum, Cattell, Daniel Longaker, and Alexander McAlister arrived at the house on Mickle Street and went ahead despite the objections. Longaker testified to Walt's consent to a post-mortem, given the previous December. Harrison Allen, who seems to have witnessed the bequest, corroborated. Naturally, all agreed that it was for the good of science, and that was enough for Dercum.

It is not clear whether George Whitman was ever informed of the removal of his brother's brain. The next day, the reporter for The Press wrote that the assembled physicians

were met by Lawyer [Thomas] Harned who stated to them the objections to a postmortem raised by George Whitman. The physicians thoroughly discussed the matter. They said that their purpose was not the satisfaction of professional curiosity; they believed that an autopsy on Whitman would reveal knowledge of great value to science. . . Mr. Harned stated that he desired to be in a position as having nothing to do with 
the matter. The physicians stated that they had discussed the subject of a post-mortern examination with Mr. Whitman in December last, and he had assented to it.

In a separate discussion, earlier the same day, an ulterior motive surfaced:

It was stated yesterday that the poet was a member of the Anthropometric Society, each member of which bequeaths his brain to the organization for scientific purposes, and that that body proposed to claim his brain. This report was denied by his nurse, Warren Fritzinger, who says that he was not a member of any organization except the Brooklynites, a Brooklyn organization to which he was elected a member as a personal compliment three or four years ago.

It is difficult to confirm anyone's membership in the A.A.S. At one time the organization boasted over 300 members, yet only a few dozen of them ever went public about it. Of these, only a handful wrote their intentions into their wills. Most of the membership seems to have sealed the pact with nothing more than a handshake. Whitman might well have made this gesture of solidarity, but as a practical matter, it would have been a hollow one unless both he and his brother had put their consent in writing, which they did not. Not a single membership card or brain bequest form has turned up to this day for Whitman or any member of the Brain Society. Nor is it clear who might have asked Whitman to join, although there are many candidates. Silas Weir Mitchell, J.K. Mitchell, and William Osler immediately come to mind, but their contact with Whitman spanned the years leading up to the founding of the society, and did not extend much beyond it. Daniel Longaker is a more likely suspect.

There is no direct proof that Longaker belonged to the Anthropometric Society, but it seems likely. He had studied under some of the society's founders, and he traveled in the same circles as other A.A.S. members. Unfortunately, little else is known about Longaker. Traubel provided the lone clue to his involvement with the A.A.S. when he wrote: "Met Longaker in Philadelphia and Dr. Cattell and found from them that W. had indeed consented in December (Harrison Allen commemorating with $\mathrm{L}$.) to a post-mortem after death." 44 The occasion had been Whitman's bout of fever. Thinking his patient near death, Longaker might well have brought Harrison Allen, then the president of the Brain Society, over to Mickle Street to initiate Whitman into the club. Traubel suggests that this is precisely what happened.

Immediately upon returning to the lab with Whitman's brain, Henry Cattell should have gone right to work on it, and the work would have taken some time. "The hardening process must not be hastened if thorough success is desired," he wrote in Notes. By this he meant several months up to a half year. There are several ways to pickle a brain, involving a variety of injections and baths. Judging by the present condi- 
tion of the brains in the A.A.S. collection, the fact that they still rest on cotton batting, Cattell probably favored a process that would have required at least two months to complete:

An open jar, bucket, or wash-basin is one-quarter filled with absorbent cotton, and Müller's fluid is added until the vessel is about one-half filled. The brain, after being removed from the body and weighed, is carefully placed in the center of the vessel and more fluid is added, until the brain is well covered. If this be done there is no danger that the brain will decompose, even in summer. . . . The position of the brain is altered on the next day and the fluid changed. . . The fluid is changed again on the third day, then every other day for three successive times, twice a week for the next three weeks, and once a week for the next three weeks. ${ }^{45}$

During these two months of fluid changing there would have been many opportunities to drop the brain, but only in the initial weeks would it have been so fragile that a fall would have destroyed it.

For lack of even a single piece of direct evidence, the saga of Whitman's brain, wrapped in the larger story of the Anthropometric Society, is mired in speculation. The alleged chain of events bobs along on a murky pool of circumstantial evidence, with only one fact beyond reasonable doubt. Or is it? Did Henry Cattell leave 328 Mickle Street that day with Walt Whitman's brain in his gupsack?

In September of 1898 the death of William Pepper and the reading of his will served to remind reporters that the Brain Society still existed, that it was still worth a half-page feature. The members generally kept a low profile, and none would go on the record when a reporter from the New York Herald came to Philadelphia to investigate. The story he filed, like almost everything that has been written about the A.A.S., leaves tantalizing but unverifiable clues. Its most likely source, given the inside information it contains, was Henry Cattell, still the society's prosector and also at the time still a demonstrator of morbid anatomy at the university. (In 1899, he left to become a coroner and a medical editor. Edward A. Spitzka assumed his role as the brain society's prosector in 1902.)

Under a headline proclaiming "Three Hundred Men Pledged Their Brains to Science," the Herald added, somewhat less credibly, "Seventy Have Already Died; and Their Gray Matter Reposes in the Archives of the Wistar Museum in Philadelphia." But the records of the Wistar Institute indicate there were never more than two dozen elite brains on the premises (there are twenty-two in the collection at present), and as of 1902, when Spitzka made his initial inquiries, there were only ten. (The other fifty or so probably belonged to executed criminals or patients of asylums, and were disposed of long ago.) Several of the brain 
donors were high-profile men, and the acquisition of their brains had been made very public, Whitman's notable among them. But the Herald reporter, apparently unaware of published accounts, passed along a curious version of events that seems to have come straight from Henry Cattell:

Less than a year before . . . Dr. Cattell had made an effort to secure the brain of Walt Whitman, the poet, but had encountered the vigorous opposition of the venerable bard's family. Nevertheless he made the autopsy on March 27,1892, and weighed and examined the brain, although he was not permitted to take away the tissue. ${ }^{46}$

This is easy enough to refute. Both Horace Traubel and Thomas Harned would have known if Cattell had been prevented from taking the brain away. The only explanation for this story, assuming that Cattell was indeed the source, is that he was covering for himself. He had dropped the brain and then, in a manner of speaking, tried to sweep it under the carpet.

The bits and pieces of evidence that have emerged since Edward Spitzka revealed the loss of Whitman's brain do not defy explanation. It is still possible to cobble together a plausible scenario based on the autopsy report and on Henry Donaldson's finding. Although it cannot be proven, such a scenario might at least help to quell some needless, and often incorrect, speculation.

Despite making occasional revelations to the press, the members of the American Anthropometric Society tried to keep their activities under wraps. Early joiners like Osler and Mitchell spoke openly about the new club. But within a few years the society's inner circle began to shun the press. They quickly found out how delicate negotiations with surviving relatives could be. They themselves held a dispassionate view of their own cerebra, but few people outside of their circle warmed to their plan. It is not surprising, then, that Longaker kept quiet about the society. In December of 1891, when he and Harrison Allen visited Whitman, and, thinking him to be on the verge of death, secured his permission to remove and study his brain, they would not have expected any problems, as long as they kept their agreement secret. They assumed they would be performing the autopsy, and that a gentlemen's agreement would suffice. Whitman himself may well have forgotten the incident after surviving the crisis.

As for the Herald's contention that Cattell was prevented from taking away the brain, the fact that it was weighed further weakens the case. It is unlikely that Cattell packed an accurate scale with his autopsy kit. The sense conveyed by the autopsy report is one of haste. The cloud 
of George Whitman's disapproval hung over the proceedings. Cattell must have succeeded in bringing the brain back to a laboratory.

But what laboratory? In 1907, both the Wistar Institute and Jefferson Medical College came under fire, possibly because at that time the brains in the society's collection could be found in both places. In addition, both Spitzka and Dercum taught at Jefferson and collaborated with the Wistar Institute. But in the spring of 1892 , Dercum had not yet left Penn for Jefferson, the Wistar Institute did not exist, and Cattell had no connection to either place. As a demonstrator of anatomy at the University of Pennsylvania, the natural place for him to take Whitman's brain would have been Logan Hall, at the corner of 36th and Spruce Streets, the home of the medical school. At that time, the top floor of Logan Hall housed the Wistar-Horner Museum of anatomical specimens. This is where both he and Dercum had their laboratory and where they stored their specimens.

Henry Donaldson's account does not conflict with this. When he checked "the files of the Wister Institute," he was probably consulting the records of the Wistar-Horner Museum, which was later absorbed by the Wistar Institute (which was built just across the street from Logan Hall in 1894). Unfortunately, these files no longer exist. The files of the present-day Wistar Institute, which go back to its founding, mention the other brains belonging to the Anthropometric Society, but not Whitman's. ${ }^{47}$

Cattell's autopsy report and his purported statements to the Herald are easy to explain as the obfuscations of a guilty man. The autopsy report, written in Cattell's own hand from notes made by Traubel at the scene, makes a compelling claim: "The brain was removed by Dr. Dercum, and is now, after having been hardened, in the possession of the American Anthropometric Society. This Society, which has been organized for the express purpose of studying high-type brains, intends to first photograph the external surfaces and then make a cast of the entire brain. After this, careful microscopic observations will be made by competent observers." 48 If true, this would have to have been written six to eight weeks after the autopsy, after the brain had hardened. It would then contradict Donaldson. But there is a strong possibility that, rather than lying, Cattell wrote this shortly after the autopsy, anticipating what would have been the case by the time the report was eventually published. At some point, of course, the brain was destroyed, probably within weeks of the autopsy. It could have happened in many ways. Although the very word "gupsack" suggests all kinds of nasty possibilities, it probably was dropped in the lab, as legend has it, perhaps by Cattell (after all, he was the assistant), or during the risky process of making a cast of the hemispheres.

There is one other possibility. Cattell's established modus operandi was one of loss through negligence. Spitzka was too cagey, or dip- 
lomatic, to point a finger directly at Cattell, but purposely or not, he dropped some hints. By implication, it was Cattell who had ruined the brains of Andrew Parker and J. William White through neglect. It was Cattell who had lost the brains of Dr. and Mrs. Kerlin. It was Cattell who was charged with the upkeep of Allen's and Pepper's brains, and had allowed them to become flattened. And it was Cattell who bore responsibility for the handling and safekeeping of Whitman's brain. Spitzka did not offer up Cattell to the press, nor did they sift the facts and root him out as the prime suspect.

To put the matter in perspective, Cattell was hardly a villain. Anatomical specimens, wet specimens, are difficult to maintain. They come and go, are misplaced and lost through accidents and neglect. Anatomists are trained to view human tissue objectively, as a research tool. If brains in jars, as Rudolph Wagner's work attests, have a long potential shelf life, interest in their research potential has a half-life measurable in months. Besides, what else could Cattell be expected to do? If he had dropped the brain before writing the autopsy report, he would not have been eager to own up to it, to have the fact advertised in 'Traubel's commemorative volume, In Re Walt Whitman, for all his colleagues to see. It wasn't just his own reputation that was at stake. For the Anthropometric Society, it would have been a public relations disaster.

To his credit, in the autopsy report Cattell does his best to praise the man and the brain. He makes allowances for the effects of illness and age, and bumps the brain weight up to fifty-six ounces at "mental maturity." This type of spin is typical of post-mortem reports in which the brain weights of great men fell short of expectations. The examination of the brain, much like an obituary, was typically used as an opportunity to celebrate the man and his accomplishments. If the brain did not measure up, at least on the scales, it was often reassessed using more favorable criteria.

Henry Cattell resigned as a demonstrator of anatomy at Penn in 1897 in order to devote more time to editing medical journals and medical reference books. In doing so, he effectively stepped down as prosector for the Anthropometric Society. Editing seems to have run in the Cattell family. His brother, the renowned psychologist James McKeen Cattell, edited many journals, including the Psychological Review, the Scientific Monthly, and Science, among a very long list of accomplishments. (He also helped to found the American Association of University Professors in 1915.) As for Henry, he seems to have gotten out of the brain business just in time.

When William Osler returned to Philadelphia in 1894 to deliver the address at the dedication of the new Wistar Institute, he spoke glow- 
ingly of the new "cerebral anatomy, particularly the study of the surface of the brain":

... gradually a new phrenology on a scientific basis has replaced the crude notions of Gall and Spurzheim.... [W]e are gradually reaching a knowledge of the physical basis of mental phenomena ... the correlation of intelligence and brain weight, of mental endowment and increased convolution of the brain surface . . .49

But the brains of the Anthropometric Society, both living and dead, never justified Osler's enthusiasm. Henry Donaldson understood that a collection of elite brains could not sustain a research program and that the institute would have to diversify. (Today the Wistar Institute is primarily engaged in cancer research.) By 1910 the brains were of historical, if not nostalgic, interest. Near the end of his career, in 1928, Donaldson conducted a study of the brains of Osler and two other professors, probably out of a residual fraternal loyalty. ${ }^{50}$ It seemed a shame to waste them. He concluded that the brains were well-nourished, as were the minds they once contained, but otherwise unremarkable. Donaldson's own brain was the last to enter the collection, in 1938. No one has studied it.

Had Whitman's brain survived, it would have been examined, described, drawn, and praised by Edward A. Spitzka along with the six other brains of eminent scientists and scholars. The specimen would then have been returned to the vault in the basement of the Wistar Institute, and forgotten. Such has been the fate of almost all so-called "elite" brains--oblivion. In the rush to judge Henry Cattell, it should be pointed out that the American Anthropometric Society was one of hundreds of scientific societies that sprouted up at that time, and then disappeared without leaving much of a trace. By 1901, its two living founders, Francis Dercum and Spitzka's father, could not tell the younger Spitzka where the brains were being kept. They had no idea. In 1908, when Spitzka tried to reconstruct the history of the society, he could find no archives, no records of any kind. ${ }^{51}$ The founders of the Brain Society had acted on the enthusiasm of a moment in the history of science that turned out to be a passing phase. Had someone not dropped Whitman's brain, they would hardly be remembered at all.

Not that elite brains studies ended right there. At various times, opportunity and motive have converged to produce new case studies, to revive old theories or inspire new ones, only to meet again with skepticism or outright rejection. Einstein and Lenin are the most famous cases in point. ${ }^{52}$ The brain that rocked physics and the brain that shook the world also startled science without changing it. Studies dealing with personality types rather than famous individuals have fared better. Recently, researchers in Germany have found a structural anomaly in the auditory cortex of professional musicians, for example. ${ }^{53}$ No one yet knows what to make of this result. 
Edward Spitzka never recovered from his bitter experience in 1907. He would enjoy some success as the editor of two editions of Gray's Anatomy, and as head of the new Daniel Baugh Institute of Anatomy at Jefferson Medical College. But he never lived up to his potential. While still in his twenties, he began to drink heavily. He also began to suffer paranoid delusions that ex-convicts were stalking him in revenge for his brain snatchings at the prisons years earlier. In 1913 he suffered a nervous breakdown, resigned his chair at Jefferson, and moved to New York, where he took over his father's private neurological practice. ${ }^{54} \mathrm{He}$ died suddenly of a stroke in 1922, at the age of forty-six. In his will, he stated his desire to have his body sent to the Baugh Institute, and his brain to the Anthropometric Society. ${ }^{55}$

In response to a query about the Anthropometric Society in June of 1920, Francis Dercum, who was still the society's president, would only say that "the brains, which I am glad to say did not accumulate very rapidly, were deposited in the Wistar Institute of Anatomy and in 1907 six were studied by Dr. E. A. Spitzka." ${ }^{56}$ The remark is typically vague. Did he mean that he was glad that the members did not die off in great numbers, or was he expressing relief that the venture hadn't amounted to much? Probably the latter. After Spitzka's death, Dercum did not step forward to claim brain or body. Nor did he make any attempt to retrieve the brains of society members that were still in Spitzka's possession. Spitzka was buried at Mount Vernon cemetery in Westchester County, and his brain collection, numbering some 600 specimens, including his own father's brain, vanished. Almost a decade later, in 1931, Dercum succumbed to a heart attack while opening a meeting of the American Philosophical Society, of which he was also president. His brain was not removed for study.

As for Whitman, the evidence may implicate Cattell, but it does not rule out the possibility, however remote, that the brain will show up some day in a dusty attic or dank cellar vault. Nor can anyone say with certainty that if it did, it would not reveal something new about the mind of the good gray poet. But the checkered history of elite brain studies should temper enthusiasm for such a prospect. Even such a storied brain as Einstein's is now regarded by neuroanatomists as of historical interest only. Similarly, Whitman's brain would have no scientific value beyond pinpointing the source of his many strokes. Which is not to say that it has no value at all. Even if its fate remains unknown, Whitman's brain opens a window onto an important but overlooked part of his life, his fascination with anatomical science and his friendships with the men who practiced it. It also brings onto the stage some important supporting characters, notably Silas Weir Mitchell, William Osler, and Daniel Longaker, who get short shrift in Whitman biographies. 
The story may not have an ending, but it does have a coda of sorts. In 1912, Edward Anthony Spitzka sat for the last in a series of portraits of eminent men painted by Thomas Eakins. ${ }^{57}$ In frail health, and two years away from death, Eakins could barely hold his brush. This would be his last painting, and would remain unfinished, except for the depiction of a plaster brain cast which Spitzka cradles in his right hand. (It was painted in by Eakins's wife.) As Eakins left the work, Spitzka stands in ghostly outline, unrecognizable, still waiting to be immortalized. In the 1930 s the canvas was cut down from a full length portrait to make it more marketable, and the image of the brain was discarded, leaving nothing more than the indistinct outlines of a presumably great man. The painting now resides, out of sight, in a storage room of Washington's Hirshhorn Gallery.

\section{University of Massachusetts, Amherst}

\section{NOTES}

This essay has been adapted from the author's forthcoming book, Brainspotting, which will be published by Doubleday in 2004 .

1 William Sloane Kennedy, The Fight of a Book for the World (West Yarmouth: Stonecraft Press, 1926), 139-140.

2 "Brain of Walt Whitman is Lost by Carelessness," Camden Daily Courier (December 5,1907$), 1$.

3 Leonard Warren, Joseph Leidy: The Last Man Who Knew Everything (New Haven: Yale University Press, 1998).

4 Edward A. Spitzka, "Memo for the Use of the Members of the Committee of the American Anthropometric Society," January 3, 1906.

5 Spitzka changed the wording slightly in his 1907 paper to include the infamous "careless assistant."

6 Edward A. Spitzka, "The Development of Man's Great Brain," Connecticut Magazine 60 (April, May, June, 1905), 327. Spitzka would tone down the rhetoric in his 1907 paper, but only slightly.

7 "Scientists Attack Dr. Spitzka's Brain Structure Theory," North American (December 6, 1907), 1 .

8 "Brain of Walt Whitman is Lost by Carelessness," Camden Daily Courier (December 5,1907$), 1$.

9 Stephen M. O'Keefe, "Disappearance of Whitman's Brains Stirred Furor in '07," Camden Courier-Post (October 27, 1969), 38.

10 "'No blame can attach to me,' said Dr. Spitzka, whose book just issued contains a description of how the brain was lost. 'I had nothing to do with its keeping. I decline to discuss what the executors of the poet may say." "Loss of Poet's Brain Roils His Executors," North American (December 7, 1907), 6. 
11 First proposed in 1798 in a letter to Baron de Retzer, Gall's four points can be found in many places, including his last work, Sur les fonctions du cerveau et sur celles de chacune de ses parties, vol. 1 (Paris, 1822), vi.

12 For a good discussion of how Gall's core argument was undermined by Spurzheim's elevation of cranioscopy over organology, see T. H. Leahy, Psychology's Occult Doubles: Psychology and the Problem of Pseudoscience (Chicago: Nelson-Hall, 1983).

13 Moritz Benedikt, Anatomical Studies Upon the Brains of Criminals, trans. E.P. Fowler (New York: DaCapo Press, 1981), 157.

14 Robert Florey, a French writer, actor, and experimental film director, signed on as the original director of Frankenstein in 1931. He began adapting a draft of the screenplay, contributing many of the film's signature scenes (including the creation scene). Florey was replaced by James Whale and received no screenwriting credits.

15 Leslie A. Marchand, Byron: A Biography, vol. 3 (New York: Knopf, 1957), 12321233. See also Spitzka's "A Study of the Brains of Six Eminent Scientists and Scholars," 207, where he cites his own sources for the Byron legend.

16 Edward A. Spitzka, "A Study of the Brains of Six Eminent Scientists and Scholars Belonging to the American Anthropometric Society," Transactions of the American Philosophical Society 21 (December 1907), 177.

17 Spitzka did Gall a disservice by listing his brain weight at 1198 grams, a figure that has been picked up by many writers since, including Stephen Jay Gould in The Mismeasure of Man (New York: Norton, 1981). Erwin H. Ackerknecht and Henry V. Vallois, in Franz Fosef Gall: Inventor of Phrenology and His Collection (Madison: Department of History of Medicine, University of Wisconsin Medical School, 1956), 66-67, give the correct weight of 1316.5 grams, then make the usual allowances for atrophy due to old age. Even Spitzka agrees that Gall's brain exceeded 1400 grams during his prime. Ironically, Gall's critics have used his "meager" brain weight, as Gould describes it, to attack Gall's work, seemingly unaware that the correlation of brain size and intellect is a principal tenet of Gall's discarded theory.

18 Rudolph Wagner, Vorstudien zu einer wissenschaftlichen Morphologie und Physiologie des menschlichen Gehims als Seelenorgan (Gottingen, 1860). This is generally referred to as Vorstudien I. Wagner produced a follow-up study in 1862 , Vorstudien II, in which he discusses the elite brains, with no new results. Wagner died in 1865 before he could complete his brain project.

19 The debate over the localization of brain function and the significance of brain weight dominated the agenda of the Sociéte d'Anthropologie from February, 1861, to February, 1862, and continued with less regularity over the next three decades. The minutes are contained in Bulletins et Memoires de la Société d'Anthropologie Paris, principally in volumes 2 and 3.

20 Spitzka's "A Study of the Brains" (1907), in addition to cataloguing famous brains, serves as a complete bibliography of post-mortem reports on great men and women. Spitzka liked lists, as do most of us. Although the brain weights are unreliable, for a variety of reasons, it is almost impossible to resist being drawn into the brain-weight game.

21 The subject of an autopsy society was first broached at the October 19, 1876, meeting of the Société d'Anthropologie (Bulletin Sociëté d'Anthropologie 11). 
22 Quoted by Jean d'Echérac, "André Lefèvre," Revue mensuelle de l'Ecole d'Anthropologie de Paris 11 (1904), 383-386. There seems to be no scientific justification for preserving of a face. A death mask would seem to suffice, but anatomists, ever on the lookout for ways to overcome their students' natural squeamishness, have preserved just about every body part, and faces can indeed be found in some collections in Europe. The face of Cesare Lombroso, the father of criminal anthropology, is literally kept in a jar by the door of his anatomical collection in Turin. His brain and skeleton are nearby.

23 The anatomist Gustav Retzius initiated such a society at the Karolinska Institute in the 1890 s. Burt Green Wilder did the same, with more success, at Cornell University, where Wilder's brain and several others are still on display in the Psychology Department.

24 Edward Hungerford, "Walt Whitman and His Chart of Bumps," American Literature 2 (January 1931), 350-384.

25 Harold Aspiz, Walt Whitman and the Body Beautiful (Urbana: University of Illinois Press, 1980), 3-33.

26 Aspiz, 148.

27 Daybooks and Notebooks, ed. William White (New York: New York University Press, 1978), 2:329.

28 Leaves of Grass, Comprehensive Reader's Edition, ed. Harold W. Blodgett and Sculley Bradley (New York: New York University Press, 1965), 53, 78.

29 Horace Traubel, With Walt Whitman in Camden, 9 vols. (Various publishers, 19061996), 1:385. Hereafter WTWC.

30 WTC, 2:271.

31 Daniel Longaker, "The Last Sickness and Death of Walt Whitman," In Re Walt Whitman, ed. Horace Traubel, Richard Maurice Bucke, and Thomas B. Harned (Philadelphia: David McKay, 1893), 404. Traubel reprints one of Longaker's daily bulletins describing the same incident at greater length in $W W C, 9: 587$.

$32 W W C, 9: 579$.

33 Andrew J. Parker, "Morphology of the Cerebral Convolutions with Special Reference to the Order of Primates," Foumal of the Academy of Natural Sciences 10 (2nd series), 247-365.

34 Spitzka, "A Study of the Brains," 266.

35 "Willed His Brain to His Colleagues," Philadelphia Press (March 22, 1892), 1.

36 The result was published in 1888 by the University of Pennsylvania under the title Animal Locomotion: The Muybridge Work at the University of Pennsylvania (New York's Arno Press published a reprint in 1973). Allen contributed a monograph entitled "Materials for a Memoir on Animal Locomotion," and Dercum contributed "A Study of Some Normal and Abnormal Movements Photographed by Muybridge."

37 Henry W. Cattell, Notes on the Demonstrations in Morbid Anatomy (Including Autopsies) Delivered in the Medical Department of the University of Pennsylvania Before the Third-Year Class (Philadelphia: International Medical Magazine Co., 1894).

38 Henry W. Cattell, Postmortem Pathology (Philadelphia: J.B. Lippincott Co., 1903).

39 Cattell, Notes, 108. 
40 Cattell, Postmortem Pathology, 37.

41 WWC, 9:605. Although he noted such details as "the claw and dip of the instruments," Traubel did not say that the brain was weighed, only that, once it was extracted, Cattell immediately placed it in the gupsack.

42 Cattell, Notes 90.

43 The three block quotations that follow are taken from "An Autopsy Made on Whitman's Body," Philadelphia Press (March 28, 1892), 2.

$44 W W C, 9: 603$.

45 Cattell, Notes, 128.

46 "Three Hundred Men Pledged Their Brains to Science," New York Herald (September 4,1898 ), section 5, p. 6 .

47 Minutes of the Board of Managers. Wistar Institute Archives.

48 Daniel Longaker, "The Last Sickness and Death of Walt Whitman," In Re Walt Whitman, 406.

49 William Osler, "The Leaven of Science," Aequanimitas, 2nd ed. (Philadelphia: P. Blakiston's Son \& Co., 1919), 91.

50 Henry H. Donaldson and Myrtelle M. Canavan, "A Study of the Brains of Three Scholars: Granville Stanley Hall, Sir William Osler, and Edward Sylvester Morse," Foumal of Comparative Neurology 46 (August 15, 1928), 1-95.

51 "It is a great pity that the archives of the Amer. Anthropometric were not better conserved!" Edward A. Spitzka, letter to Burt Green Wilder, February 23, 1908 (Burt Green Wilder papers [14/26/95], Kroch Library, Cornell University).

52 Numerous articles have been written on the strange odyssey of Einstein's brain, but only a few scientific papers came of it, and they amounted to nothing of scientific value. Lenin's brain has its own bizarre history, with a similar lack of result.

53 Peter Schneider et al., "Morphology of Heschl's Gyrus Reflects Enhanced Activation in the Auditory Cortex of Musicians," Nature Neuroscience 5 (July 2002), 688694.

54 The event is described in surprising detail in a front-page spread in the March 22, 1913, edition of the North American, under the headline "Dr. Spitzka, Brain Expert, in Nervous Breakdown."

55 Last Will and Testament of Edward Anthony Spitzka, February 11, 1914. Thomas Jefferson University Archives.

56 Cited by William Feindel in "Osler's Brain Again," Osler Library Nerwsletter 64 (June 1990), 1. Harvey Cushing queried Francis Dercum in June of 1920 about Osler's membership in the A.A.S. The source is listed as the Cushing files of the Osler Library.

57 Information about Eakins's Spitzka portrait was provided by Douglas Paschall of the Philadelphia Museum of Art and Phylis Rosenzweig of the Hirshhorn Museum. 